\title{
PENGABDIAN KEPADA MASYARAKAT MELALUI PENDAMPINGAN BAGI GURU POS PAUD
}

\author{
Oleh: \\ Choirun Nisak Aulina', Vanda Rezania², Evi Destiana ${ }^{3}$ \\ 1,2,3,Dosen FIKP Universitas Muhammadiyah Sidoarjo \\ 1 lina@umsida.ac.id
}

\begin{abstract}
Abstrak
Tujuan kegiatan pengabdian pada masyarakat ini adalah untuk memberikan pendampingan tentang 1) pembelajaran yang sesuai untuk pendidikan anak usia dini, 2) manajemen pengelolaan lembaga PAUD, 3) peningkatan keterampilan orang tua siswa. Untuk mencapai tujuan tersebut, maka dilakukan beberapa kegiatan meliputi 1) pelatihan penyusunan perangkat pembelajaran dan membuat APE, 2) perbaikan manajemen lembaga PAUD, 3) pelatihan keterampilan untuk orang tua. Kegiatan pengabdian ini dilaksanakan di PAUD AI-Muslimun yang berada di desa Gempolsari dan Pos PAUD Pelangi yang berada di Ketegan ke dua sekolah mitra berada di Kecamatan Tanggulangin. Hasil dari kegiatan ini adalah terwujudnya pembelajaran yang sesuai dengan pedoman pembelajaran anak usia dini dengan tersusunnya RPPH, tersedianya alat media edukatif pembelajaran pendidikan anak usia dini, serta terlaksananya parenting bagi orang tua murid.
\end{abstract}

Kata Kunci: Perangkat Pembelajaran Anak Usia Dini, Manajemen Lembaga Pendidikan AUD, Parenting

\section{Abstract}

The aim of this community service activities is to mentoring the teachers of the post of early childhood education (POS PAUD) such as: 1) the appropriate learning for early childhood education, 2) management of PAUD institutions, 3) the improvement of parenting skills for students' guardians. To achieve these objectives, several activities are conducted, including 1) training on the preparation of learning tools and making APE (educational game tool) ,2) improving PAUD management, and 3) skills training for parents. This community service activities is held in PAUD Al-Muslimun located in Gempolsari village and Post PAUD Pelangi located in Ketegan, both schools are located in Kecamatan Tanggulangin. The result of this activity is the realization of learning in accordance with the guidance of early childhood learning with the compilation of RPPH (lesson plan for each meeting), the availability of educational media tools for early childhood education, as well as the implementation of parenting for students' guardian.

Keywords: Early Childhood Learning Device, Management of PAUD Institution, Parenting

\section{PENDAHULUAN}

Kelembagaan sebuah instansi sangatlah Pendidikan merupakan dasar utama pembangunan sumber daya manusia, dimana harus dilaksanakan secara konstruktif, komprehensif dan berkesinambungan. Konstruktif berarti berketetapan dan berkekuatan hukum dalam hal pelaksanaannya. Komprehensif dalam arti bahwa proses pendidikan mencakup semua aspek dan dimensi manusia, sehingga manusia yang dihasilkan adalah yang seutuhnya, yaitu manusia yang cerdas secara intelektual, emosional dan spiritual. Sementara berkesinambungan dalam arti bahwa pendidikan harus dilaksanakan sepanjang hayat dikandung badan (long life education) dan pendidikan untuk semua (education for all), mulai anak ketika masih dalam kandungan, taraf usia dini hingga akhir hayatnya.

Dalam rangka penyiapan sumber daya manusia maka pendidikan anak usia dini, sebagaimana diungkapkan oleh Santoso (2006), memegang posisi yang sangat fundamental. Fundamental dalam arti bahwa pengalaman pendidikan di usia dini dapat memberikan pengaruh yang "membekas" sehingga akan menjadi landasan pendidikan anak pada usia selanjutnya.

Pendidikan anak usia dini dilakukan sebagai upaya untuk membantu anak dalam meningkatkan berbagai potensi yang dimiliki sesuai dengan bakat dan minat masingmasing anak, seperti yang telah diamanahkan dalam Undang-Undang Perlindungan Anak Nomor 23 Tahun 2002 
pasal 9 menyatakan bahwa "Setiap anak berhak memperoleh pengajaran dalam rangka pengembangan pribadinya dan tingkat kecerdasannya sesuai dengan minat dan bakatnya".

Anak BALITA berada pada periode emas bagi perkembangan anak adalah dimaksudkan untuk memperoleh proses pendidikan, dan periode ini adalah tahuntahun yang sangat berharga bagi seorang anak untuk mengenali berbagai macam fakta di lingkungannnya sebagai stimulus terhadap perkembangan kepribadian , psikomotor, kognitif maupun sosialnya. Berdasarkan hasil penelitian sekitar 50\% kapabilitaas kecerdasan orang dewasa telah terjadi ketika anak berumur 4 tahun,8 $0 \%$ telah terjadi perkembangan yang pesat tentang jaringan otak ketika anak berumur 8 tahun dan mencapai puncaknya ketika anak berumur 18 tahun, dan setelah itu walaupun dilakukan perbaikan nutrisi tidak akan berpengaruh terhadap perkembangan kognitif.

Hal ini berarti bahwa perkembangan yang terjadi dalam kurun waktu 4 tahun pertama sama besarnya dengan perkembangan yang terjadi pada kurun waktu 14 tahun berikutnya. Sehingga periode ini merupakan periode kritis bagi anak, dimana perkembangan yang diperoleh pada periode ini sangat berpengaruh terhadap perkembangan periode berikutnya hingga masa dewasa. Sementara masa emas ini hanya datang sekali, sehingga apabila terlewatkan berarti habislah peluangnya.

Pos PAUD Pelangi yang berlokasi di Desa Ketegan Kabupaten Sidoajo merupakan lembaga yang terintegrasi dengan kegiatan Posyandu. Pos PAUD Pelangi tidak berbeda dengan Pos PAUD pada umumnya di Kabupaten Sidoarjo. Yang mana proses berdirinya berawal dari kegiatan Posyandu yang dilakukan oleh kader-kader PKK untuk anak-anak bayi bawah lima tahun (BALITA) dengan focus pengembangannya pada kesehatan dan gizi anak dengan kegiatan penimbangan rutin dan tambahan makanan bergizi. Namun, keberadaan Pos PAUD ini tidak di imbangi juga dengan Sumber Daya Manusia yang kompeten di bidang Pendidikan Anak Usia Dini. Hal ini terlihat dengan para pengajar/guru di Pos PAUD Pelangi adalah kader PKK yang memiliki waktu yang longgar atau mau mengajar. Kualifikasi pendidikan kaderpun rata-rata SMA yang belum berpengalaman dalan Pendiidikan Anak Usia Dini. Kegiatan yang awalnya untuk mengoptimalkan pemberian menstimulasi perkembangan anak uisa dini akhirnya tidak dapat berjalan dengan maksimal. Sehingga mengajar tidak berpedoman pada karakteristik tingkat perkembangan anak sesuai usia tapi hanya dengan perkiraan-perkiraan guru. Perangkat pembelajaranpun tidak lagi menjadi sesuatu yang penting karena memang mereka tidak faham kebutuhan sebenarnya di dunia pendidikan anak usia dini.

Alat Permainan Edukatif pun sangat minim di lembaga Pos PAUD Pelangi, meraka lebih banyak kegiatan menulis, berhitung dan mewarnai. Sehingga konsep pendidikan anak usia dini yang bermain sambil belajar pun tidak lagi menjadi pedoman penyelenggaran. Guru kurang memanfaatkan barang-barang yang ada disekitar untuk sarana pendukung pembelajaran. APE tergantung pada barangbarang jadi yang tentunya perlu biaya mahal. Padahal Pos PAUD Pelangi bukanlah profit oriented sehingga pemenuhan kebutuhan APE untuk pembelajaran pun sangat minim.

Sementara keberadaan media sangatlah penting,menurut Menurut Hamalik (2011), Fungsi media pembelajaran yaitu: 1) Untuk mewujudkan situasi pembelajaran yang efektif, 2) Penggunaan media merupakan bagian internal dalam system pembelajaran. 3) Media pembelajaran penting dalam rangka mencapai tujuan pembelajaran. 4) Penggunaan media dalam pembelajaran adalah untuk mempercepat proses pembelajaran dan membantu siswa dalam upaya memahami materi yang disajikan oleh Guru dalam kelas. 5)Penggunaan media dalam pembelajaran dimaksudkan untuk mempertinggi mutu pendidikan. Hal ini sesuai dengan konsep pendidikan anak usia dini menurut Piaget bahwa anak usia dini berada pada tahap pra operasional yang mana anakusia 2-7 tahun itu masih belum bisa berfikir secara abstrak sehingga keberadaan APE itu sangat membantu proses belajar mengajar di PAUD.

Oleh karena itu diperlukan suatu solusi sebagai upaya konkret yang dapat dilakukan, salah satunya adalah pelatihan pembuatan perangkat pembelajaran dan APE bagi kaderkader pengajar di Pos PAUD sehingga diharapkan para kader setiap mengajar dapat mempersiapkan perangkat pembelajaran sehingga proses kegiatan pembelajaran dapat lebih terstruktur sesuai dengan pencapaian kompetensi sesuai tahap usia anak. Serta guru dapat menentukan media yang sesuai dengan tema pembelajaran serta membuat APE sendiri dengan memanfaatkan 
barang-barang yang ada disekitar anak agar tidak tergantuk pada barang-barang jadi.

\section{METODE PELAKSANAAN}

Kegiatan pengabdian ini dilakukan pada dua mitra yaitu PAUD Al-Muslimun yang berada di desa Gempolsari dan Pos PAUD Pelangi yang berada di Ketegan, dimana keduanya beralamatkan di Kecamatan Tanggulangin, Kabupaten Sidoarjo.

Metode yang digunakan dalam kegiatan ini berdasar tujuan pengabdian yang telah disusun maka di susun langkah atau cara pelaksanaan sebagai berikut: 1) Pelatihan penyusunan perangkat pembelajaran dan membuat APE yaitu bagi mitra belum membuat perangkat pembelajaran dengan adanya permasalahan ini, akan memberikan suatu pelatihan dan pendampingan dalam menyusun perangkat pembelajaran sesuai dengan tingkat pencapaian perkembangan anak dan usia anak. Serta pelatihan pembuatan APE untuk mendukung proses pembelajaran. 2) Perbaikan Manajemen Lembaga Pendidikan AUD, selama ini mitra belum mempunyai sistem administrasi yang baik, dengan adanya permasalahan ini, akan memberikan suatu pelatihan dan pendampingan dalam menyusun administrasi meliputi laporan keuangan, kepegawaian, sarana dan prasarana, serta menyusun proposal ijin pendidirian Pos PAUD agar lembaga mempunyai data base yang terstruktur dan sistematis. 3) Pelatihan Keterampilan untuk orang tua, dengan adanya pelatihan keterampilan membuat aksesoris maupun boga kepada orang tua/pengantar diharapkan dapat meningkatkan perekonomian mereka.

Mekanisme kerja selama pelaksanaan program ini pertama-tama adalah tim terjun langsung ke lapangan dan melihat kondisi serta permasalahan yang dihadapi oleh mitra. Kemudian tim diskusi untuk membuat workplan (rencana kerja), yang berupa nama kegiatan serta waktu pelaksanaan. Dimana masing-masing kegiatan akan terdapat penanggung jawab, sehingga kegiatan sesuai dengan yang telah ditentukan. Selama pelaksanaan tim selalu berkoordinasi dengan mitra, sehingga dalam prosesnya mitra memahami dan dapat menjalankan secara mandiri atas teknologi yang telah ditransfer melalui kegiatan workshop/pelatihan, pendampingan secara intensif dari masingmasing kegiatan. Dalam pelaksanaan program ini tim akan selalu mengevaluasi dan melaporkan hasil dari setiap kegiatan yang telah dilaksanakan sampai semua kegiatan terealisasi. Sehingga kerjasama tim dapat terwujud, dan masing-masing anggota tim dapat mengoptimalkan potensi dan bidang pakarnya. Mitra berkontribusi dalam memberikan gambaran permasalahan sehingga tim pengusul dapat dengan jelas menawarkan solusi. Selama pelaksanaan mitra menyediakan tempat saat kegiatan (workshop atau pelatihan) dilaksanakan. Luaran yang diharapkan dalam program ini adalah adanya Pembelajaran yang sesuai untuk anak usia dini (perangkat pembelajaran dan APE), terdapatnya ijin pendirian serta data base administrasi lembaga yang terstruktur.

\section{HASIL DAN PEMBAHASAN}

Kegiatan pengabdian ini dilakukan pada dua mitra yaitu PAUD Al-Muslimun yang berada di desa Gempolsari dan Pos PAUD Pelangi yang berada di Ketegan, dimana keduanya beralamatkan di Kecamatan Tanggulangin, Kabupaten Sidoarjo.

\section{Peningkatan kualitas pembelajaran}

Dalam peningkatan kualiatas pembelajaran ini terbagi menjadi 2 bentuk kegiatan yakni pelatihan penyusunan perangkat pembelajaran dan pendampinga penyediaan APE di bagi menjadi beberapa sub kegiatan meliputi:

a. Pelatihan penyusunan perangkat pembelajaran yang sesuai dengan tahap perkembangan anak usia dini, dengan membuat Rancangan Kegiatan Harian mengacu pada tahap pencapaian perkembangan anak, selain membuat perangkat pembelajaran kami juga memberikan pendampingan microteaching yang menyenangkan untuk anak usia dini. $\mathrm{Hal}$ ini di latar belakangi setelah di lapangan kami melihat bunda-bunda PAUD lebih banyak memberikan materi membaca, menulis, berhitung dan bernyanyi tanpa memperhatikan prinsip pembelajaran anak usia dini yakni bermain sambil belajar.

b. Pelatihan pembuatan pajangan kelas kegiatan ini bertujuan untuk membekali bunda-bunda PAUD agar lebih kreatif dalam menciptakan lingkungan belajar yang menyenangkan dan ramah anak. Sebelumnya ruangan kelas sangat kosong tanpa ada hiasan sehingga kelas terasa hampa. Hal ini pastinya berdampak pada 
motivasi belajar anak yang mudah jenuh atau bosan. Perubahan desain kelas dari sebelum di lakukan pendampingan dengan sesudah di lakukan pendampingan terlihat sebagaimana Gambar 1.

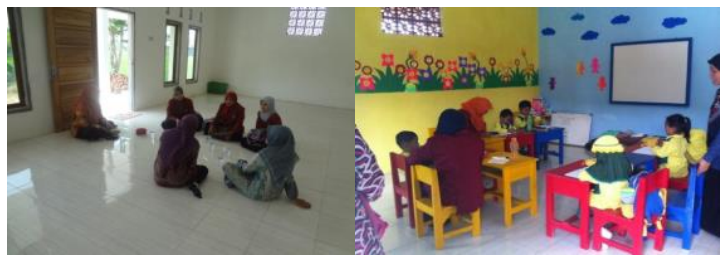

Gambar 1. Pendampingan pengelolaan kelas, dari kiri ke kanan perubahan desain kelas sebelum dan sesudah pelaksanaan pendampingan

c. Pelatihan dan pendampingan membuat APE sesuai dengan tema. Bunda-bunda PAUD selama ini membagi kegiatan dengan materi bukan tema sehingga kegiatan cenderung monoton. Sehingga setelah kami menjelaskan dan mendampingi penentuan tema pembelajaran kami pun mendampingi bunda-bunda PAUD untuk membuat media sesuai dengan tema yang telah disepakati yakni 10 Tema yang terdiri dari 1) diri sendiri, 2) kebutuhanku, 3) lingkunganku, 4) binatang, 5) Rekreasi, 6) Tumbuhan, 7) Alam Semesta, 8) Api, Air dan Udara, 9) Kendaraan, 10) Alat Komunikasi. Sebagaimana terlihat pada Gambar 2 pembuatan APE dan juga pengadaan permainan penunjang kegiatan stimulasi anak.

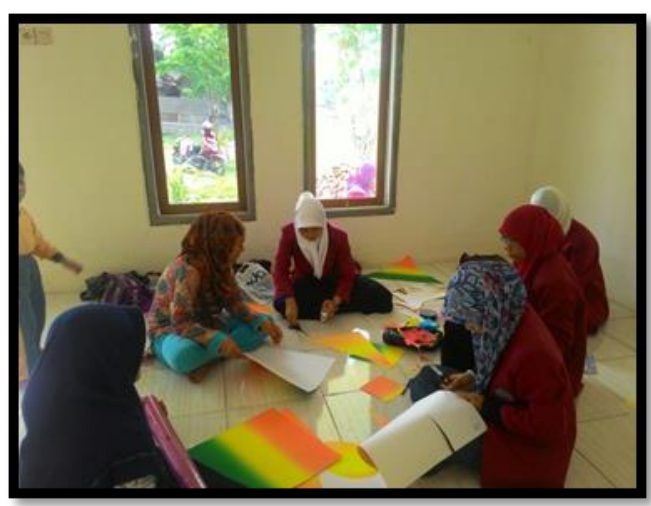

Gambar 2. Pendampingan pembuatan APE

\section{Peningkatan Manajemen pengelolaan lembaga PAUD}

Peningkatan manajemen pengelola lembaga di jabarkan dalam beberapa kegiatan, diantaranya pendampingan dan pelatihan manajemen administrasi terkait buku-buku apasaja yang harus dipenuhi oleh lembaga. Kegiatan ini diawali dengan melakukan pendataan buku-buku yang di butuhkan di PAUD diantaranya buku induk, absensi, anecdotal record, notula rapat, dll sebagaimana Gambar 3.

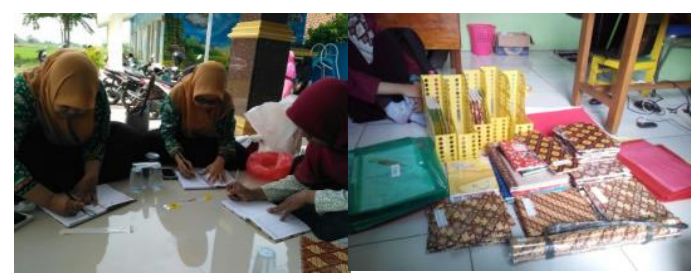

Gambar 3. Pendampingan penyusunan administrasi sekolah

\section{Peningkatan Keterampilan orang tua siswa}

Dalam kegiatan ini kami melakukan parenting kepada wali murid dengan materi pola asuh untuk anak usia dini. Dalam kegiatan ini juga akan membahas pentingnya pendidikan anak sejak dini sehingga wali murid lebih memperhatikan kebutuhan pendidikan anak-anak mereka.

\section{SIMPULAN DAN SARAN}

Peningkatan kompetensi guru dalam pengajaran sangat penting, karena keberhasilan proses pembelajaran tergantung pada guru. Dalam kegiatan pengabdian ini telah tiga hal utama yakni 1) peningkatan kualitas pembelajaran dengan pelatihan penyusunan perangkat pembelajaran, pelatihan pembuatan pajangan kelas, serta pelatihan pembuatan APE. 2) peningkatan manajemen pengelolaan lembaga PAUD meliputi pengurusan ijin operasioanl serta pemenuhan buku-buku administrasi. 3) peningkatan keterampilan orang tua siswa dengan pelaksanaan parenting terkait dengan pola asuh dan tahp perkembangan anak usia dini. Respon guru terhadap materi dan pendampingan sangat positif sehingga guru sudah dapat mengimplementasikan materi yang di dapat baik pada pengembangan perangkat pembelajaran, pemgembangan media pembelajaran maupun program kegiatan sekolah dengan baik. Dan pastinya ini berdampak pada kesadaran masyarakat terhadap pentingnya pendidikan anak usia dini. 
Diharapkan kedepan bunda-bunda PAUD dalam kegiatan pembelajaran selalu mengacu pada konsep pembelajaran anak usia dini yakni belajar sambil bermain serta harus sesuai dengan tahap pencapaian perkembangan anak usia dini.

\section{DAFTAR PUSTAKA}

Suyanto, Slamet. 2005. Konsep Dasar Pendidikan Anak Usia Dini. Jakarta: Depdiknas Dirjen Pendidikan Tinggi,.

Adams, D.M. 1975. Simulation Games: An Approach to Learning. Ohio: Jones Publishing Company.
Badru Zaman, dkk. 2007. Media dan Sumber Belajar TK. Jakarta: Penerbit Universitas Terbuka.

Rusman, 2012. Belajar dan Pembelajaran Berbasis Komputer. Bandung: Alfabeta.

Uno, Hamzah B dan Lamatengngo, Nina. 2011. Teknologi Komunikasi dan Informasi Pembelajaran. Jakarta: PT Bumi Aksara.

Hamalik, Oemar. 2011. Proses Belajar Mengajar, Jakarta : Bumi Aksara. 